$\therefore$ LA-UR- $9 \%-20$ \%

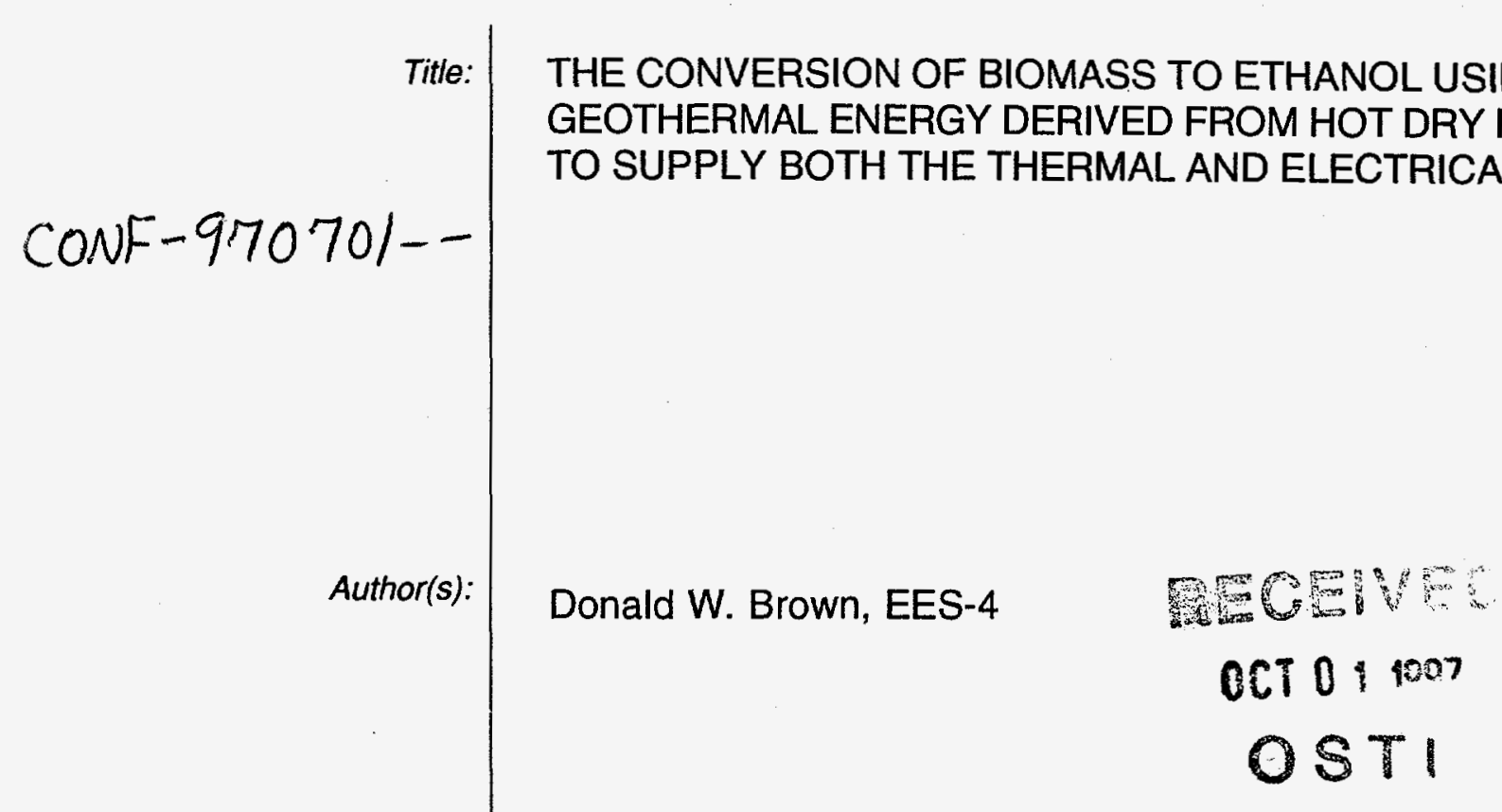

Submitted to:

32nd Intersociety Energy Conversion Engineering Conference, Hilton Hawaiian Village, Honolulu, $\mathrm{HI}$, July 27-August 1, 1997

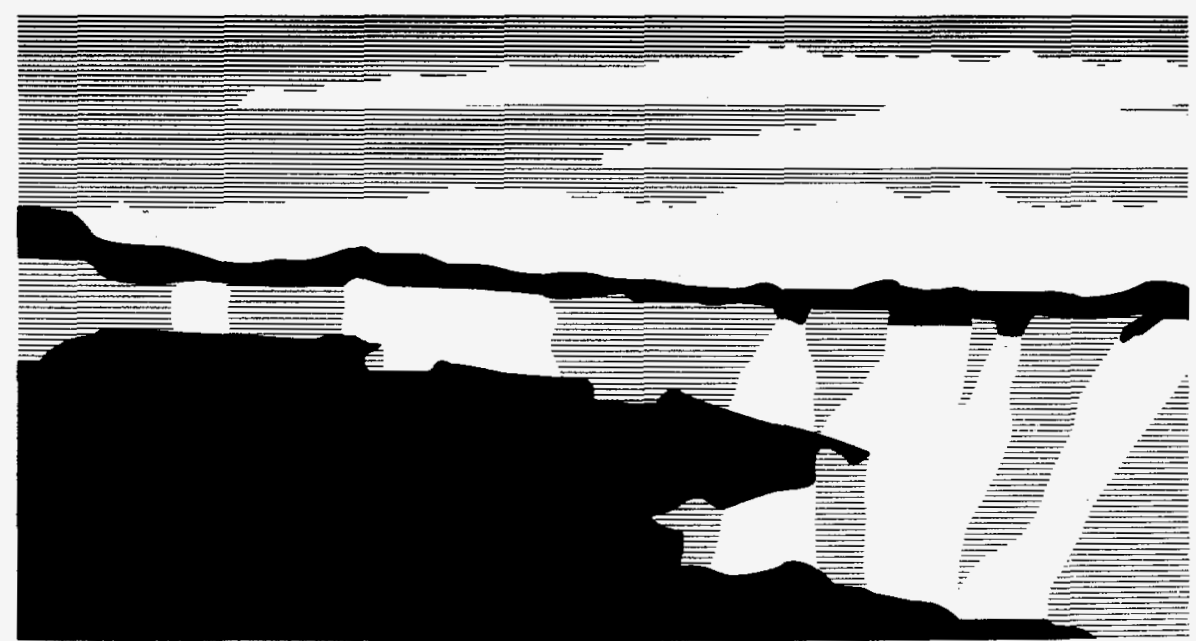

Los Alamos National Laboratory, an affirmative action/equal opportunity employer, is operated by the University of California for the U.S. Department of Energy under contract W-7405-ENG-36. By acceptance of this article, the publisher recognizes that the U.S. Government retains a nonexclusive, royalty-free license to publish or reproduce the published form of this contribution, or to allow others to do so, for U.S. Government purposes. The Los Alamos National Laboratory requests that the publisher identify this article as work performed under the auspices of the U.S. Department of Energy. 


\section{DISCLA MMER}

Portions of this document may be illegible in electronic image products. Insges are produced from the best available original document. 


\section{DISCLAIMER}

This report was prepared as an account of work sponsored by an agency of the United States Government. Neither the United States Government nor any agency thereof, nor any of their employees, make any warranty, express or implied, or assumes any legal liability or responsibility for the accuracy, completeness, or usefulness of any information, apparatus, product, or process disclosed, or represents that its use would not infringe privately owned rights. Reference herein to any specific commercial product, process, or service by trade name, trademark, manufacturer, or otherwise does not necessarily constitute or imply its endorsement, recommendation, or favoring by the United States Government or any agency thereof. The views and opinions of authors expressed herein do not necessarily state or reflect those of the United States Government or any agency thereof. 


\title{
THE CONVERSION OF BIOMASS TO ETHANOL USING GEOTHERMAL ENERGY DERIVED FROM HOT DRY ROCK TO SUPPLY BOTH THE THERMAL AND ELECTRICAL POWER REQUIREMENTS
}

\author{
Donald Brown \\ Los Alamos National Laboratory \\ Earth and Environmental Sciences Division \\ Los Alamos, New Mexico 87545
}

\begin{abstract}
The potential synergism between a hot dry rock (HDR) geothermal energy source and the power requirements for the conversion of biomass to fuel ethanol is considerable. In addition, combining these two renewable energy resources to produce transportation fuel has very positive environmental implications. One of the distinct advantages of wedding an HDR geothermal power source to a biomass conversion process is flexibility, both in plant location and in operating conditions. The latter obtains since an HDR system is an engineered system, where the surface fluid production and injection conditions of flow rate, pressure, temperature, and water chemistry are under the control of the operator. The former obtains since, unlike a naturally occurring geothermal resource, the HDR resource is very widespread, particularly in the western US, and can be developed near transportation and plentiful supplies of biomass.

Conceptually, the pressurized geofluid from the HDR reservoir would be produced at a temperature in the range of $200^{\circ}$ to $220^{\circ} \mathrm{C}$. The higher enthalpy portion of the geofluid thermal energy would be used to produce a lower-temperature steam supply in a countercurrent feedwater-heater/boiler. The steam, following a superheating stage fueled by the noncellulosic waste fraction of the biomass, would be expanded through a turbine to produce electrical power. Depending on the lignin fraction of the biomass, there would probably be excess electrical power generated over and above plant requirements (for slurry pumping, stirring, solids separation, etc.) which would be available for sale to the local power grid. In fact, if the hybrid HDR/biomass system were creatively configured, the power plant could be designed to produce daytime peaking power as well as a lower level of baseload power during off-peak hours.

The exhaust from the steam turbine, at a temperature of about $110^{\circ} \mathrm{C}$, would be used to supply the heating needs of the ethanol distillation/dehydration section of the plant, which typically represents about $70 \%$ of the overall ethanol plant thermal power requirements. The residual heat contained in the geofluid exiting the HDR power plant boiler section could be used to supply the heating requirements of the biomass pretreatment stage or other lower-temperature plant heating requirements. After mechanically separating the solid fraction
\end{abstract}

in the process feed stream upstream of the distillation section, additional geothermal heat would be used to dry and harvest this lignin-rich solid waste which would be used in a lignin-fired superheater, increasing both the efficiency and power output of the steam turbogenerator. Finally, the waste water stream from the distillation section would be combined with the cooled geofluid exiting the pretreatment section heat exchangers and reinjected into the HDR reservoir, eliminating the costly tertiary treatment of this waste water stream. The high temperature and pressure available in the HDR reservoir could potentially destroy the organic content of the waste water -- originally with a high biological oxygen demand (BOD) -- and permit the water to be recycled back through the HDR surface plant and reinjected again.

\section{INTRODUCTION}

The synergism between two ubiquitous renewable energy resources -- geothermal energy derived from the vast resource of Hot Dry Rock (HDR) in our country, and biomass-derived fuel ethanol - has been investigated, not as a detailed engineering study by rather as an initial conceptual study. This is because the details of the optimum (from both cost and efficiency standpoints) biomass conversion process are still being developed (see for instance, Grohmann et al., 1990). Further, a biomass-to-fuel-ethanol plane might well be optimized in a somewhat different configuration if a reasonably priced and plentiful source of HDR-derived thermal energy were available. When one considers the uniqueness and flexibility of both the thermal and electrical power outputs from an HDR geothermal power-generation system, as discussed below, there should be many opportunities for optimization between the HDR power supply and the thermal and electrical power requirements for the various stages of the biomass-to-fuel-ethanol conversion process.

Obviously, if lignin heating and conventional electric power were to be specified in the design phase of a biomassto-fuel-ethanol plant, then the only real engineering study would involve reducing the heat and power demands to minimize the use of both electrical and thermal power per gallon of ethanol produced. This would most probably be done with a modicum of additional capital investment for 
equipment used for system optimization and heat recuperation over and above the "standard" biomass-to-ethanol plant. However. if environmental externalities were to be considered in designing the biomass conversion process, the preferred system might well involve the use of HDR geothermal energy.

\section{Hot Dry Rock Geothermal Energy}

The heat contained in the accessible regions of the earth's crust -- down to about $6 \mathrm{~km}$-- represents one of largest resources of thermal energy available to mankind (Tester et al., 1989). Because of the shear size of the HDR resource, it is generally included with other forms of renewable energy (e.g., hydropower, solar, and biomass) in the broader context of renewable energy options. Compared to the limited hydrothermal geothermal resource in the form of naturally occurring hot water and steam, the HDR resource is considerably larger and very broadly distributed in those much more numerous crustal regions where no significant natural porosity exists (Duchane, 1995).

For the past 25 years, researchers at Los Alamos National Laboratory have been engaged in developing the technology for creating fully engineered geothermal reservoirs in hot, but essentially impermeable, crystalline rock. The HDR reservoirs that have been repeatedly tested since the late 1970's at the Laboratory's Fenton Hill HDR test site in north-central New Mexico were created by hydraulic fracturing techniques, and subsequently circulated with water to mine heat from the hot rock. The results from this testing have indicated that it is practical to operate a commercial-scale HDR heat mining facility to produce thermal power on a sustained basis.

The heat mining concept is shown schematically in Figure 1. An initial well would be drilled into hot basement rock, to a depth where a commercially useful rock temperature exists (usually at least $150^{\circ} \mathrm{C}$ ). Water would then be injected into an isolated zone at the bottom of this well at pressures high enough to open the preexisting joints in the surrounding rock mass. As pumping continued, an interconnected array of pressurized joints would be progressively extended outward from this initial wellbore, forming a man-made geothermal reservoir in a region where insignificant permeability had previously existed. Seismic monitoring techniques would be used to follow the growth of this pressure-stimulated region and to determine its depth, orientation, and approximate dimensions (House, 1987). This region of greatly enhanced porosity and permeability -- the HDR reservoir - would then be connected to the surface through a pair of production wells drilled to intersect the extremities of the reservoir region.

Three attributes of HDR geothermal energy are of particular note when coupled to the biomass production of fuel ethanol:

1. The very widespread distribution of the HDR resource in the western half of the US, making this type of power supply essentially non-site-specific,

2. The demonstrated ability of an HDR energy supply system to rapidly follow varying power demands, both for the biomass conversion processes and in providing excess electrical power during periods of peak demand,

3. The non-polluting nature of the HDR energy source as a replacement for fossil-fuel-derived energy supplies.

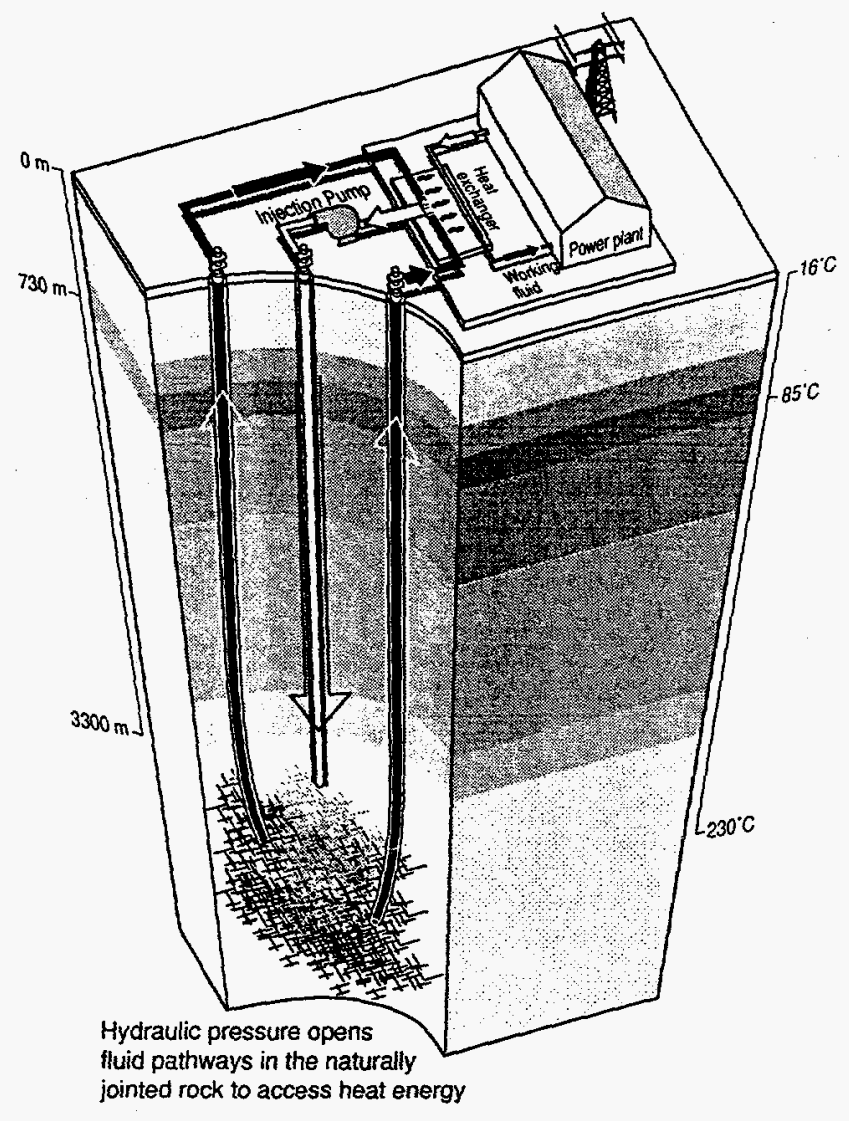

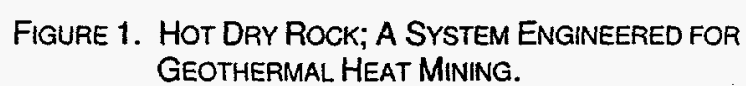

\section{THE DISTRIBUTION OF THE HDR RESOURCE IN THE CONTINENTAL US}

As shown in Figure 2, the HDR geothermal resource - as indicated by the distribution of geothermal temperature gradients, is concentrated mainly in the western half of the continental US. Figure 2 shows that within the "lower 48 " states, above-average temperature gradients $\left(30\right.$ to $\left.45^{\circ} \mathrm{C} / \mathrm{km}\right)$ exist in much of North and South Dakota, Nebraska, and Kansas. In addition, about half of the states of Texas, Louisiana, Arkansas, Colorado, Utah, New Mexico, Wyoming and Montana as well as significant portions of the other western states also exhibit temperature gradients of 30 to $45^{\circ} \mathrm{C}$ or higher. Of more importance to this discussion involving biomass conversion, however, is the very large portion of the upper Great Plains - much of the very fertile heartland of the country - that has a significant HDR geothermal potential. In particular, I would like to draw attention to the western portion of state of Nebraska, a region with both high temperature gradients and a significant agricultural base. The temperature gradients in this region are quite well defined due to the presence of numerous oil wells drilled through the sedimentary section and into the crystalline basement at depths of from 5000 to $7000 \mathrm{ft}$ (Sims, 1990; Sims et al., 1991). 


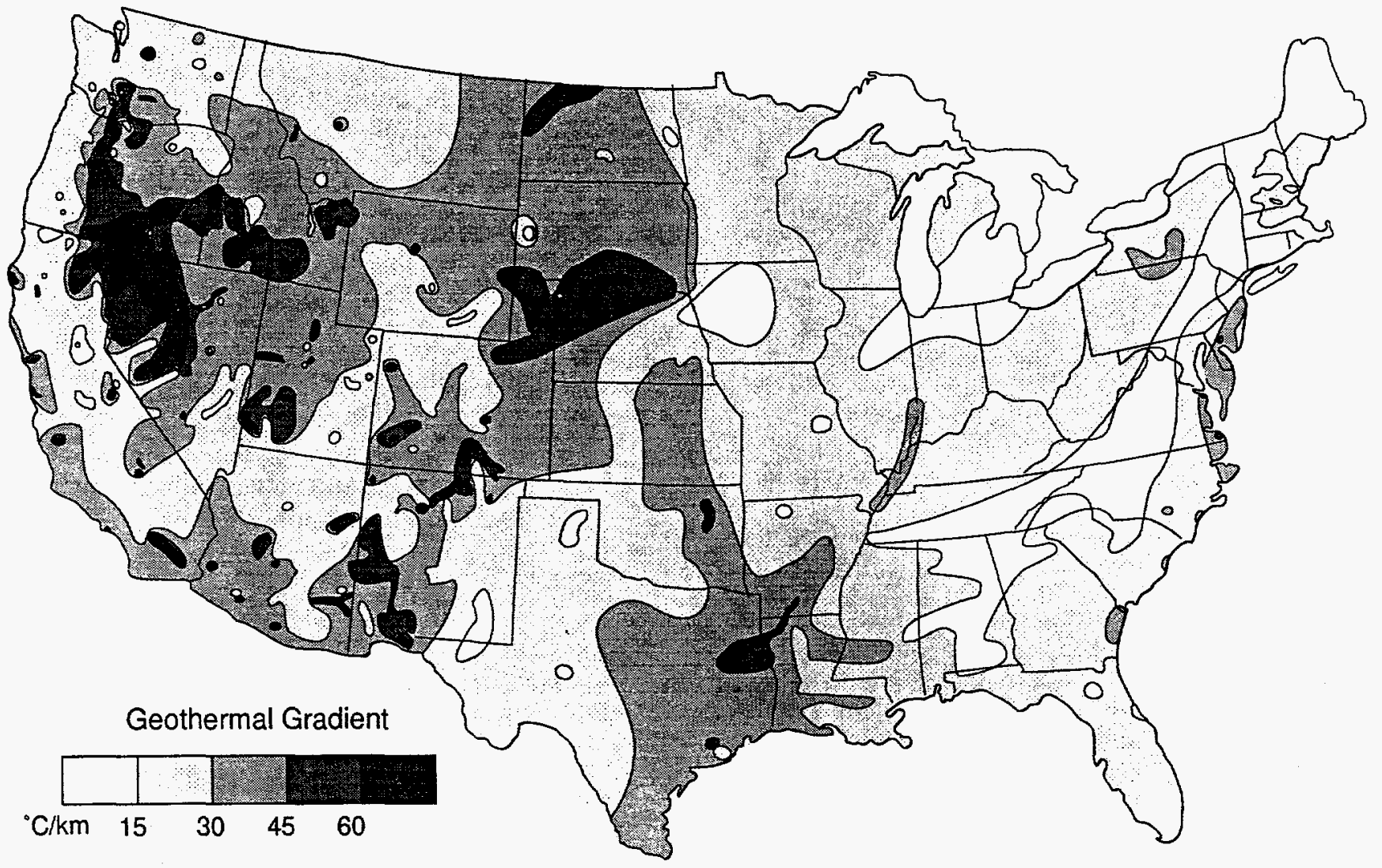

Figure 2. The Distribution of Geothermal Temperature Gradients in the "Lower 48" States.

\section{SUGGESTED BIOMASS SUPPLY}

On what remains of the wild prairie, we find cool season grasses, warm-season grasses, legumes, and members of the sunflower family. This is what all of Kansas used to be, and what some 400 million acres of North America once was, from the Rockies to the Mississippi and from Saskatchewan to Texas. In this drought-resistant mixed grassland, the predominant features were that the soil was deep and fertile and that the plants were mostly perennials, with 75 to $85 \%$ of the biomass existing below ground level (Chadwick, 1995). It is from this native ecosystem, now mostly vanished, that one should look for guidelines in establishing a mixedspecies grassland as the potential biomass source for the production of fuel ethanol. Once established, this mixedgrassland should require only a modicum of water or fertilizer, and only a minimum of insecticides or herbicides, when compared to present methods of agriculture. In other words, this reestablished mixed-grassland ecosystem would be topsoil-preserving, water-conserving, and much less waterpolluting.

One native species existing in the tallgrass prairie is switchgrass, a biomass feedstock that has been extensively studied (e.g., Reshamwala et al., 1995), and is apparently coming into favor as the energy crop of the future because it can be grown on marginal croplands, harvested in a conventional manner, and does not have the lead time for income production that nonherbaceous energy crops (such as poplar) have. Therefore, for this initial study, the biomass considered for conversion to fuel ethanol is switchgrass, a deep-rooted perennial plains grass that exhibits a number of favorable characteristics when considered as a biomass feedstock (Parrish et al., 1997). According to Reshamwala et al. (1995), a representative switchgrass composition (dry) would be: cellulose $(45 \%)$, hemicellulose $(31 \%)$, lignin $(12 \%)$, protein $(4 \%)$, and other $(8 \%)$. However, as mentioned above, the preferred biomass source, according to several experts on the native prairie ecosystem (e.g., W. Jackson of the Land Institute in Salina, Kansas), would me a mixed grassland, which would be more tolerant of insects and more drought resistant than any single monoculture, regardless of its other attributes.

\section{THE BASIC COMPONENTS OF A BIOMASS CONVERSION SYSTEM}

Although the details of the "preferred" grass-based fuelethanol conversion process are still evolving and therefore differ to some degree from concept to concept, the basic components appear to be reasonably well established as shown in Figure 3. They are as follows:

1. A pretreatment step where the cellular structure of the biomass is destroyed, the hemicelluloses hydrolyzed to monomeric sugars, and the cellulose substrate made available for subsequent enzyme-catalyzed hydrolysis to glucose. The protein content would be extracted prior to fermentation while the residual lignin and other waste biomass would be dried and used as boiler fuel. Two competing pretreatment processes are presently under consideration: 


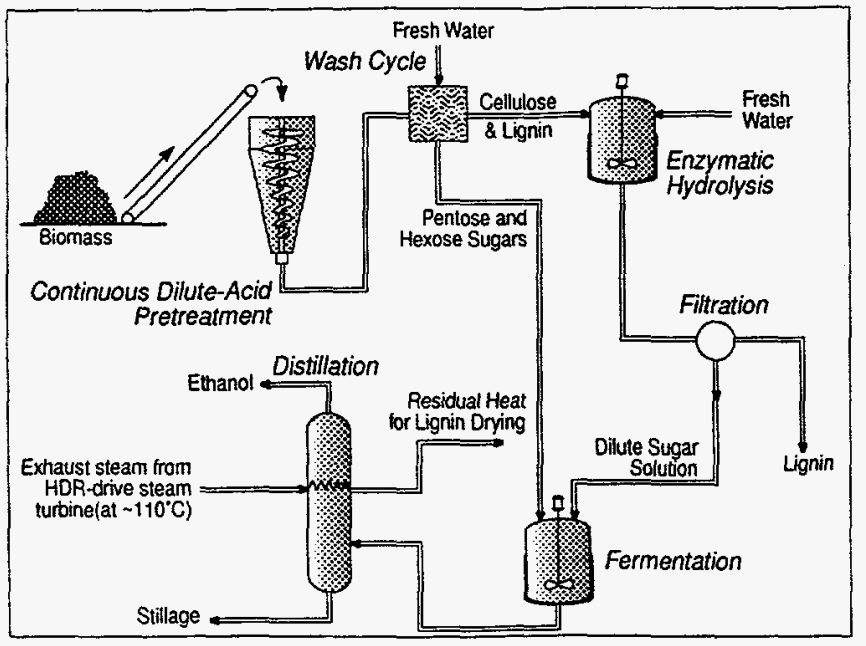

Figure 3. Production of Ethanol Based on Enzymatic HYDROLYSIS

dilute acid hydrolysis and high-temperature "autohydrolysis" (Grohmann et al., 1990). A recently developed third pretreatment process, ammonia fiber explosion (AFEX), produces both cellulose and hemicellulose substrates suitable for subsequent enzymic hydrolysis (Reshamwala et al., 1995). Some of the drawbacks of the dilute acid hydrolysis pretreatment include the simultaneous decomposition of the released sugars, the high cost of corrosion-resistant equipment, and the post-processing of the acid solution. For the AFEX approach, the handling and recirculation of the ammonia is the major drawback, while for the hightemperature "autohydrolysis" pretreatment, the major drawback appears to be the high temperatures and pressures involved. Recent experimental and numerical studies of the "autohydrolysis" pretreatment of biomass prior to enzymic hydrolysis (Lynd et al., 1997 and Ladisch et al., 1997) investigated batch-mode reactors employing hightemperature $\left(200-260^{\circ} \mathrm{C}\right)$ aqueous soaking for up to one hour per batch - analogous to the common kitchen pressure cooker, but at much higher temperatures and pressures.

2 . The generally accepted second step is the simultaneous saccharification and fermentation (SSF) of the batch mixture from the initial pretreatment step. In the SSF step, cellulase enzymes are used to convert the cellulose to glucose while at the same time a judiciously selected microorganism is used to ferment the resulting sugar to ethanol. This step is essentially exothermic, although careful temperature control is required (in the neighborhood of 35 to $40^{\circ} \mathrm{C}$ ). However, renewed interest in separate saccharification and fermentation steps is apparent (Stenberg, et al., 1997), and is the process shown in Figure 3 . The principal advantages are the ability to ferment all of the sugars in the same fermenter using recently developed microorganisms (Mohagheghi et al., 1997) and the ability to use a higher, more optimum, temperature in the cellulose enzymic-hydrolysis reactor.

3. The final step involves the distillation of the dilute solution of ethanol produced from the fermenter to about $95 \%$ pure ethanol. The distillation step is the most thermalenergy-intensive step in the whole process and would normally involve an initial steam temperature of about $110^{\circ} \mathrm{C}$. A final dehydration step is often added, where the remaining $5 \%$ of the water content is removed.

A detailed study has been done for the Colorado School of Mines to assess the use of a geothermal resource to provide the thermal energy required for the production of fuel-ethanol from biomass (Coury and Associates, 1978). In their study, using corn or wheat as the feedstock and with heat recuperation, a total heat requirement of $42,000 \mathrm{Btu} /$ gallon ethanol was required. An interesting result of their study was that the heat requirements for the distillation stage -- using industrially proven technology - represented about $70 \%$ of the total plant heat load. This study would imply that the coupling of an HDR geothermal heat source to a biomass conversion process would primarily involve a modest reengineering of the distillation/dehydration sections to accommodate the $110^{\circ} \mathrm{C}$ steam discharge (at above atmospheric pressure) from the steam turbine. It has been estimated (Tester et al.; 1989) that a direct-heat-use HDR geothermal system could produce heat in this temperature range for about $\$ 2.40 / 10^{6} \mathrm{Btu}$ throughout much of the Great Plains, which is reasonably competitive with current prices for natural gas.

\section{THE ABILITY TO RAPIDLY VARY THE HDR THERMAL POWER OUTPUT TO FOLLOW PLANT REQUIREMENTS}

One of the unique aspects of an HDR thermal power supply is that the output can be varied over a wide range on a time scale of only a few minutes. The basis for this variable behavior is twofold. First, the pressurized HDR reservoir functions as a fluid capacitor with the capability of being rapidly discharged (Brown 1996a). Second, in a steady-state mode of production, the thermal output can be varied by up to a factor of 10 by merely adjusting the production backpressure via a surface throttling valve (Brown, 1994). Employing a PC-based digital control system, the Fenton Hill reservoir was operated over a wide range of thermal power outputs during the most recent phase of testing from 1992 through 1995 (Duchane, 1995).

\section{WHAT AN HDR-POWERED ETHANOL PRODUCTION SYSTEM MIGHT LOOK LIKE}

Obviously, for any serious commercial effort, one would rely on an established ethanol plant designer (e.g., Raphae] Katzen Assoc. International) to optimize the combined biomass-to-fuel-ethanol system utilizing HDR-supplied heat and electrical power sources. However, the general framework of how the combined system might look is reasonably clear at this juncture.

One fairly well established criterion concerning the HDR system is the desirability of operating the earth circulation in a pressurized, closed-loop, liquid-water configuration -- as previously shown in Figure 1. The primary reason for this criterion is the desire to retain any reservoir-derived gases (e.g., $\mathrm{CO}_{2}$ and $\mathrm{H}_{2} \mathrm{~S}$ ) in solution, and to prevent any contamination of surface waters with reservoir fluids that may contain traces of arsenic, fluoride, or other possible reservoir-derived contaminants.

The first step in the design of an HDR system would be the specification of the reservoir rock temperature, to provide a surface production temperature appropriate to the biomass 
conversion plant - probably in the range of $170^{\circ}$ to $200^{\circ} \mathrm{C}$ (Brown, 1996b). However, with the availability of the residual lignin from the biomass processing (dried using HDR power plant waste heat) as a boiler fuel for superheating, one is left with numerous working-fluid and heat-exchanger options.

If electrical power generation -- actually cogeneration in the normal sense of the word - were to be a major component of the overall biomass-HDR plant design, it would probably be most appropriate to utilize the higher-temperature geofluid to raise steam in a counter-current feedwater-heater/boiler heat exchanger unit in combination with a lignin-fired steam superheater. This superheated steam would then be used in a compact steam turbine to generate electricity for the overall facility power needs. Excess power could be sold to the grid, particularly during periods of peak electrical power demand, if the ethanol plant were structured such that the maximum electrical power requirements occurred during the evening hours. The turbine would be unusual in that the exhaust would be controlled at an elevated pressure (about 20 psia) to produce the $110^{\circ} \mathrm{C}$ steam supply needed for the distillation/dehydration section of the ethanol plant. If configured appropriately, these coupled HDR-powergeneration/ethanol-distillation systems would utilize the majority of the produced HDR thermal power.

If desirable for autohydrolysis, the still-hot geofluid exiting the feedwater-heater/boiler section of the HDR power plant, at a temperature in the range of $140^{\circ} \mathrm{C}$ to $160^{\circ} \mathrm{C}$, could be reheated with additional lignin or other combustible plant wastes to bring the geofluid back up to a temperature of about $200^{\circ}$ to $220^{\circ} \mathrm{C}$. This fluid would then be used as the heat source in the biomass pretreatment system, particularly if high-temperature "pressure cooking" of the aqueous-slurry biomass supply were the selected pretreatment method. Residual heat from the pretreatment stage could be used for other lower-temperature ethanol plant heating needs such as lignin drying, space heating, and wastewater treatment.

\section{REFERENCES}

Brown, D.W., 1994, "Summary of Recent Flow Testing of the Fenton Hill HDR Reservoir," Proceedings, 19th Workshop on Geothermal Reservoir Engineering, Stanford Univ., Stanford, CA, Jan. 18-20, 1994, SGP-TR-147, pp. 113-116.

Brown, D.W., 1996a, "The Geothermal Analog of Pumped Storage for Electrical Demand Load Following," Proceedings, 31st Intersociety Energy Conversion Engineering Conference, Washington, D.C., Aug. 11-16, 1996, Vol. 3, pp. 1653-1656.

Brown, D.W., 1996b, "The Hot Dry Rock Geothermal Potential of the Susanville (CA) Area," Geothermal Resources Council Transactions 20, 441-445.

Chadwick, D.H., 1995, "What Good is a Prairie?", Audubon, Nov-Dec 1995, pp. 37-46, pp. 114-116.

Duchane, D.V., 1995, "Hot Dry Rock: A Versatile Alternative Energy Technology," SPE 30738, presented at the SPE Annual Technical Conference and Exhibition held in Dallas, USA, 22-26 Oct. 1995.

House, L., 1987, "Locating Microearthquakes Induced by Hydraulic Fracturing in Crystalline Rock," Geophysical Research Letters 14, (9) 919-921.
Grohmann, K., C.E. Wyman, and M.E. Himmel, 1990, "Potential for Fuels from Biomass and Wastes," Chap. 21 in Emerging Technologies for Materials and Chemicals from Biomass, R.M. Rowell, T.P. Schultz, and R. Narayan, Eds., ACS Symposium Series 476, pp. 354-392.

Ladisch, M., J. Weil, A. Sarikaya, D. Rau, J. Goetz, C. Ladisch, M. Brewer, and R. Hendrickson, 1997, "Pretreatment of Lignocellulosic Materials by Pressure Cooking in Water: Experimental Results and Engineering Analysis," presented at the 19th Symposium on Biotechnology for Fuels and Chemicals, Colorado Springs, CO, May 4-8, 1997.

Lynd, R.L., M.S. Laser, S.G. Allen, and M.J. Antal, Jr., 1997, "Pretreatment of Lignocellulosics with Liquid Hot Water and Subsequent Conversion to Ethanol," presented at the 19th Symposium on Biotechnology for Fuels and Chemicals, Colorado Springs, CO, May 4-8, 1997.

Mohagheghi, A., K. Evans, M. Finkelstein, and M. Zhang, 1997, "Cofermentation of Glucose, Zylose and Arabinose by Mixed Cultures of Two Genetically Engineered Zymomonas mobilis Strains," presented at the 19th Symposium on Biotechnology for Fuels and Chemicals, Colorado Springs, CO, May 4-8, 1997.

Parrish, D.J., D.D. Wold, J.A. Balasko, J.T. Green, M. Rasnake, and J.H. Reynolds, 1997, "Switchgrass as a Potential Biofuels Feedstock," presented at the 19th Symposium on Biotechnology for Fuels and Chemicals, Colorado Springs, CO, May 4-8, 1997.

Reshamwala, S., B.T. Shawky, and B.E. Dale, 1995, "Ethanol Production from Enzymatic Hydrolysates of AFEXTreated Coastal Bermudagrass and Switchgrass," Applied Biochemistry and Biotechnology 51/52, 43-55.

Sims, P.K., 1990, "Precambrian Basement Map of the Northern Midcontinent, U.S.A.," Dept. of the Interior, U.S. Geol. Survey Miscellaneous Investigations Series Map I2214.

Sims, P.K., Z.E. Peterman, T.G. Hildenbrand, and S. Mahan, 1991, "Precambrian Basement Map of the TransHudson Orogen and Adjacent Terraris, Northern Great Plains, U.S.A.," Dept. 'of the Interivr. U.S. Geol. Survey Miscellaneous Investigations Series Map I-1853-A.

Stenberg, K., C. Tengborg, M. Larsson, E. Palmquist, Z. Szengyel, M. Galbe, B. Hahn-Hagerdal, and G. Zacchi, 1997, "Different Process Configurations in Enzymatic Production of Ethanol from Softwood," presented at the 19th Symposium on Biotechnology for Fuels and Chemicals, Colorado Springs, CO, May 4-8, 1997.

Tester, J.W., D.W. Brown, and R.M. Potter, 1989, "Hot Dry Rock Geothermal Energy -- A New Energy Agenda for the 21 st Century," Los Alamos National Laboratory report LA11514-MS, Issued: July 1989. 